\title{
Gram-Negative Microaerophilic Coccus
}

National Cancer Institute

\section{Source}

National Cancer Institute. Gram-Negative Microaerophilic Coccus. NCI Thesaurus. Code C122322.

Any sphere-shaped bacteria that contains low levels of peptidoglycan in its cell wall and stains pink with the Gram staining technique and that require oxygen to grow but are poisoned by high concentrations of oxygen. 